DENIS SOLODOV

Warmia and Mazury University in Olsztyn,

Poland

denis.solodov@uwm.edu.pl

ORCID iD: https://orcid.org/0000-0003-2884-9420

IRENEUSZ SOŁTYSZEWSKI

Medical University of Warsaw, Poland

irsolvet@wp.pl

ORCID iD: https://orcid.org/0000-0003-1128-8129

\title{
THE SEARCH FOR MISSING PERSONS IN THE EASTERN EUROPEAN COUNTRIES: A LEGAL PROCEDURE AND ORGANIZATIONAL FRAMEWORK
}

\begin{abstract}
The article addresses the issue of human disappearances in four Eastern European countries - Russia, Belarus, Ukraine, and Lithuania. Although there are significant discrepancies between the four concerning economic welfare and individuals' mobility, their search procedures are quite similar. Besides, domestic police forces are dealing with similar external challenges, including increased crossborder migration and human trafficking. There have been several studies regarding human disappearances and police search investigations in those countries. However, there have been no comparative reviews of this kind so far. The authors analyzed noteworthy similarities differences between the four countries regarding an existing legal framework and the ways the search for the missing people are being organized in each country. The authors also highlighted the areas that require improvement, pointing to some common deficiencies such as a selective approach to human disappearances, the lack of specialized search units within the national police forces, and the somewhat limited use of the modern internet-based media. The issues relating to the identification of unknown human, which is a crucial part of the police search investigations, were addressed as well.
\end{abstract}

KeYwoRDs: police law, missing person investigation, criminal disappearances, forensic human identification, organizational framework 


\section{INTRODUCTION}

Human disappearances are the issue of great concern in modern European countries, especially in Eastern Europe, where often there is a lack of sufficient resources to address this problem timely and effectively. The number of people vanishing each year is alarmingly high, as well as the number of unsolved missing person cases. Poland is not an exception. National statistical numbers show that in some Eastern European countries the number of people gone missing is high than in others (Table 1). It is hard to pinpoint the exact reason for those disproportions, especially in an objective way due to the lack of relevant objective data. There is no exhaustive catalogue of the motive and factors behind human disappearances. As studies show, people who went missing could be of different age, social and professional background, educational level and living area - city or rural (BLau, 2016, pp. 191-192). There are diverse reasons for human disappearances. It could be the desire to escape from home in the case of minors, mental or physical illness, such as somatic disease or dementia (Greene at al., 2019, pp. 241-253) in the cases regarding the elderly. There are several identified risk-generating conditions, such as autism (Mogavero, 2019, p. 430), depression and personal breakdowns relating to financial, family or professional crisis. Only a mall number of people who went missing became crime victims. Often it is the desire to break off all contacts with one's family or suicide behind the person's disappearance (Morewitz, 2016, p. 95). The challenge is to ensure that the existing police procedures address the issue efficiently and flexibly.

Table 1. The numbers of missing adults and minors in four countries and Poland (Source: national statistical data for 2018)

\begin{tabular}{|c|c|}
\hline Country & $\begin{array}{c}\text { Number of the missing persons/missing } \\
\text { minors/population number }\end{array}$ \\
\hline Poland & approx. 19 thous. $/ 5$ thous. $/ 37,97 \mathrm{mln}$. \\
\hline Lithuania & approx. 4 thous. $/ 100 / 2,79 \mathrm{mln}$. \\
\hline Belarus & approx. 12 thous. $/$ no data/9, $47 \mathrm{mln}$. \\
\hline Ukraine & approx.. 9 thous. $/$ no data $/ 41,98 \mathrm{mln}$. \\
\hline Russian Federation & approx. 76 thous. $/ 14$ thous. $/ 144,5 \mathrm{mln}$. \\
\hline
\end{tabular}


The choice of the four countries was not accidental. Not so long ago all belonged to the same legal space, thus, similar organizational frameworks regarding missing person investigations were adopted. This is still true in the case of the Russian Federation, Belarus and Ukraine - the three countries were until recently actively engaged within the Commonwealth of Independent States. Within the Commonwealth, the international legal framework regarding citizens' disappearances was established deepening the cooperation between the Member States on the issue (International treaty on the international search for missing persons with the Commonwealth of the Independent States, 2010; Joint decision of the Governments within the Commonwealth of Independent States on the international search for missing persons, 2015). In all four countries, the police is the main body tasked with the search for the missing people regardless of the reasons behind particular disappearance. The police investigators exercise broad discretion in the qualification of each case and the way it is handled. One of the problems with this model is related to criminal disappearances. They are the ones which require immediate attention. Unfortunately, sometimes the police are unable to timely recognize the nature of the disappearance and proceed accordingly. Another issue is the lack of specialization within the national police forces. The search for the missing persons is one of the many tasks allocated to the police, so there are no adequately prepared units dedicated to the task. Traditionally, this area of police work is covered by internal regulations and classified procedures providing some basic rules. These rules are frequently vague and lacking in details. Crucial areas such as public assistance and media coverage are often omitted or mentioned only superficially. One of the main areas of concern is the status of the missing persons' relatives who are treated only as a source of information, not as the ones needed to be helped and taken care of them. According to the European Court's judgement in the case Varnava and others v. Turkey, "the phenomenon of disappearances imposes a particular burden on the relatives of missing persons who are kept in ignorance of the fate of their loved ones and suffer the anguish of uncertainty". In a somewhat similar case - Çakıcı v. Turkey, the Court found that the disappeared persons' relatives' suffering has a character and dimension distinct from 
the emotional distress stemming inevitably from the violation itself. In the existing police procedures, the relatives' rights and obligations are unclear, thus, require more specific provisions. The Issue paper of the Council of Europe and the Commissioner for Human Rights stresses that "the analysis of the phenomenon and the actions taken by states to tackle it must be victim-centred, that is, focused particularly on the families of missing persons and of victims of enforced disappearance who are subjected to extreme suffering" (Issue paper, 2016).

The paper aims to show current legal provisions and organizational framework for the search of the missing persons in four Eastern European countries - Belarus, Ukraine, Lithuania and Russia. To achieve this purpose the authors highlighted and explored noteworthy similarities and differences between the countries concerning police search procedures and pinpointed the ways those procedures could be improved to address the problem of human disappearances timely and effectively. Since the issue concerning the identification of unknown human remains is of particular importance to the abovementioned topic, the paper also addressed this aspect of the missing person investigations. The article consists of two blocks. The first one concentrates on the legal frameworks for the search for missing persons applied in each country, including official police procedures. The second block is dedicated to current organizational issues related to missing person investigations. The structure of the state bodies responsible for the search is described to show important structural flows.

\section{NATIONAL LEGAL FRAMEWORKS}

\section{The Russian Federation}

As the members of the Commonwealth of the Independent States, the Russian Federation and the Republic of Belarus both participate in the treaty on the international search for missing persons signed by national representatives in Dushanbe on 30 October 2015. To facilitate the search, specially designed Interstate Information Database was introduced in 2016. Its technical infrastructure is maintained by Russia, namely by the Informational and Analytical Centre of the Russian Ministry of Internal 
Affairs (Article 7). The Member State can submit the request for its citizen's whereabouts in the case where there are reasons to believe that the person who has gone missing migrated to another state, for example, searching for a better-paid job. The treaty imposes the obligation of conditionality regarding the content of the Member States' requests (Articles 5, 6). As a general rule, each Member State is expected to cover all expenses related to the request (Article 8).

In the Russian Federation, related legal provisions can be found in the federal law and internal police regulations. The latter ones (with a few exceptions) are classified. They provide, among others, the definition of a missing person. According to the ministerial decree of 5 May 1993 No. $213 \mathrm{dsp}$ on the organization of the identification of unknown human remains, live persons who cannot provide identification information and missing person investigations, a missing person is the one who has gone missing without apparent reason and whose whereabouts are unknown (Nikitin, 2013, pp. 155-156). The joint regulations of the Ministry of Internal Affairs, Attorney General Office and Bureau of Investigations of 16 January 2015 on the examination of the reports about human disappearances provide for the initial search procedures and contain general recommendations.

Other provisions on the search for the missing persons in Russia can be found in the federal law of 8 August 1995 No. 144-FZ on covert operations, the law of 25 July 1998 No. 128-FZ on the state-provided fingerprint registration, and the law of 3 December 2008 No. 242-FZ on the state-provided genetic registration.

Under Article 2 of the federal law on covert operations, one of the objectives of the police clandestine activity is the search for the missing persons. The search begins when there is information about the person who has gone missing or unidentified human remains (Article 7). The law was amended in 2019 allowing the police to intercept cell phone communications and obtain geolocation data in the cases regarding missing children, provided that the police obtained the written consent from one of the child's parents or another legal representative. Within nest 24 hours the police must inform the court about the use of such data and obtain the court's warrant within 48 hours (Article 8). 
The law on covert operations provides an exhaustive list of police clandestine operations laying down legal conditions that should be met in each case (Article 6). Regarding the search for the missing, three types of police clandestine operations are proved to be useful. Firstly, the police are entitled to obtain biological samples for comparative analysis from the missing person's relatives. Their consent, in this case, is not required. Secondly, the police are authorized to search the missing person's last know address, workplace or any other location for such samples and other relevant information. Thirdly, the police are entitled to identify covertly persons of interest using CCTV recordings with the help of automated facial recognition technologies or other available methods of human identification.

Under the joint regulations of the Ministry of Internal Affairs, Attorney General Office and Bureau of Investigations of 16 January 2015 on the examination of the reports about human disappearances, every missing person notification must be processed by the police regardless of time and place of the disappearance, the availability of the information about the person's current whereabouts, the amount of data on the person including the availability of his or her photographs, and the history of previous disappearances. The police officer on-duty must write down time, place and other relevant circumstances, including the data about the missing person's personal life, mental or emotional state, his or her known contacts and plans. It does not matter how much time pass since the disappearance. Existing legal provisions do not provide for such a limitation period. Nonetheless, the public and media still believe that such a rule exists. There have been several cases where this conviction hindered the police investigation (There are more chances to survive, 2020).

In the case of crime-related disappearances, the procedure is different. The missing person notification goes to the criminal investigator onduty. The investigator sets up an investigative group, consisting of police operatives, a police dog operator, and forensic technicians. The abovementioned joint regulations provide for a catalogue of the facts which may indicate that the disappearance is criminal in nature. It includes the following circumstances: 
- there is no indication that the person who went missing was going to leave his or her last-known place of residence;

- the missing person did not have any disease that might cause sudden death, memory loss or disorientation in time and space;

- the search in the last known place of residence reveals that the missing person left private documents, things, clothes, money, medication or other objects of particular personal importance;

- the person who went missing intended to attend important events, such as exams, doctoral dissertation, business trip or medical examination;

- the missing person had on him or with him a large sum of money or other valuable objects in the time of his or her disappearance, which might attract the attention of criminals;

- there is no information about the persons' whereabouts for a long time;

- it is impossible to make contact with the missing person through SMS, email, online messengers and other means of electronic communication;

- there is an indication that the disappearance might be related to the transfer of ownership of valuable assets;

- a search in the last known place of the residence revealed unmistakable traces indicating that the crime was committed, such as the indications of a fight taken place, blood, broken furniture, etc.;

- the lack of timely notification from the missing person's relatives;

- the person who went missing was involved in some conflicts at home or workplace, including the conflicts related to his or her public activities;

- there were threats to the missing person;

- the missing person was suspected of or charged with a crime;

- there was an unplanned renovation in the missing person's last known place of residence;

- the person who reported being missing is not using the money from his or her salary, pension, social aids for a long time without any logical reasons;

- the behaviour of the missing person's relatives suggests that they know that he or she won't be found alive; for example, they are selling the missing person's personal belongings, spending his or her money, begin new relationships, etc.;

- the disappearance of a pregnant woman; 
- the disappearance of high-risk persons, for example, members of a criminal organization, prostitutes, homeless persons, etc. (Section 10 of the joint regulations).

This catalogue is not exhaustive. Such a conclusion can be drawn from other facts, such as an overall criminal situation in the area of disappearance, specific local traditions including a blood feud, vendetta or clan wars. In any case, criminal investigators examine the person's last known place of stay. During the on-site examination, the investigators collect personal photographs, diaries, notes, other belongings which may provide insights into the missing person's whereabouts. Comparative samples, such as missing person's fingerprints, hairs, traces of saliva should also be secured. It is worth mentioning that the police could conduct such an examination even if there is no evidence indicating a criminal nature of the disappearance (section 7 of the joint regulations). In some cases, in particular, where the risk of the loss of potential evidence occurs, it is strongly advised to conduct a thorough examination. In the case of non-criminal disappearance, a police operative should at least visually inspect the missing person's last known place of stay. If after a few days there is no information on the missing person's whereabouts, the police operative initiates the so-called search case. It is a file case containing the collected documents. All pages must be numbered and the detailed table of content must be attached allowing the operative's supervisor to review the processing of the case. The content of a search case file is considered privileged and can not be disclosed.

Under Article 9 of the law on the state-provided fingerprint registration and art. 7 of the law on the state-provided genetic registration, all unknown human remains should be fingerprinted, biological samples should also be collected. According to Article 178 of the Russian Code of Criminal Procedure - CCP, during a crime scene investigation human remains should be photographed, fingerprinted and biological samples should be collected. It is strictly forbidden to cremate unknown human remains. The external examination of the remains should be conducted immediately on-site by a pathologist or qualified doctor. Article 196 CCP provides for an obligatory autopsy in each case where there is a likelihood of a crime being committed. 


\section{The Republic of Belarus}

Legal provisions on the search for missing persons can be found in the law of 17 July 2007 on the agencies of internal affairs, the law of 15 July 2015 on covert operations and some internal legal regulations including the publicly open joint regulations of the Belorussian Bureau of Investigations, Ministry of Internal Affairs and Ministry of Health of 25 September 2013 on the investigations into human deaths, crime scene and medical examinations regarding human remains. Other internal regulations concerning the search for the missing people are classified.

According to Article 2 of the law on the internal affairs agencies, the search for missing persons and identification of unknown human remains are the tasks assigned to the Belorussian criminal police. The law on covert operations provides for an exhaustive catalogue of clandestine police operations (Article 18), some of which can be carried out during the search for the missing. The police are authorized to conduct interviews, the searches for relevant documents and information, clandestine monitoring, obtain samples for comparative analysis, conduct open or covert on-scene inspections, make human identification, intercept communications, and use undercover agents. Detailed provisions on the police search activity are contained in classified police regulations.

The abovementioned joint regulations provide that in the cases regarding suspicious deaths an autopsy examination should be conducted by a qualified medical professional (Sections 3-5, the same rule can be found in Article 228 of the Belorussian Code of Criminal Procedure). The autopsy is not, however, obligatory if the cause of death is likely to be natural and the deceased's relatives do not insist on the examination (Section 7).

Unlike Russia, in the Republic of Belarus, there is no catalogue of the circumstances indicating that the disappearance has a criminal nature. Instead, the national legislator has introduced a specific timeframe. Under Article 167 of the Belorussian Code of Criminal Procedure, in the case when the person who went missing is not located within the first 10 days from his or her disappearance, a murder investigation should be started. This period can not be prolonged or shortened and is unjustifiable. 


\section{Ukraine}

The main legal act concerning the search for the missing persons in Ukraine is the law of 12 July 2018 on the legal status of the missing persons. The law defines a missing person as a natural person whose current whereabouts are unknown (Article 1). Under the law, the persons who went missing are divided into five categories:

- the ones whose disappearance was intentional and voluntary;

- the ones who could not provide identification information because of a severe medical condition;

- victims of crimes;

- the ones who went missing during military operations;

- the ones who disappeared while being in another country (Lubova et al., 2018, pp. 149-151).

The law also relates to the persons who went missing in emergency circumstances, including natural disasters or another dangerous event. The information about the persons who went missing and unidentified human remains is preserved in a dedicated database (Article 12). The cases regarding military-related disappearances are investigated by the governmental commission made up of the representatives from National Police, Security Service, Attorney General's Office, Ministry of Defence, and other law enforcement agencies (Article 10). The Commission manages the missing persons' database and coordinates the search for the missing carried out by the National Police and other law enforcement agencies. The law prohibits the burial of unidentified human remains without securing identification information including photographs, fingerprints and biological samples (Article 22).

The search for the missing people is the task assigned to the police operative divisions (Art. 6 of the law of 18 February 1992 on covert operations). Nonetheless, there are no specialized units dedicated to the search for the missing persons in Ukraine.

In 2018, a new type of crime was introduced to the Ukrainian Penal Code named a forced disappearance. According to Article 146.1, a forced disappearance is the disappearance which involves any form of abduction or forcible confinement committed by private persons or state officials. This 
new crime relates to the ongoing military conflict in Donbas and Lugansk regions of eastern Ukraine, where hundreds of soldiers and civilians have been reported missing over the past few years.

In the case of criminal disappearances, the provisions of the Ukrainian Code of Criminal Procedure should be applied. Under Article 238, a medical professional should be present during the on-site examination of unidentified human remains. In the case of a suspicious death, an autopsy must be performed by a forensic pathologist. The Code also provides for clandestine police operations including the obtaining of the phone's geolocation data, communication interceptions and covert monitoring of persons and places (Articles 260, 263, 267).

\section{The Republic of Lithuania}

According to the Lithuanian law on the police of 25 June 2015, the search for the missing is the task allocated to the national police. Under Article 6, the police search may concern:

- a person, who has been suspected, accused or convicted in criminal proceedings;

- a person who escaped from a specialized medical institution, thus, violating the court's order;

- a person who went missing for unknown reasons;

- the identification of unknown human remains.

The internal regulations of the Lithuanian Ministry of Internal Affairs provide for the creation of the national database on the missing persons and unidentified human remains. The term "a missing person" refers to the one whose whereabouts are unknown, and who is the subject of police search (Subsection 6.3).

The regulations also define unidentified human remains and unidentified living persons. The term "unidentified human remains" refers to a human corpse or skeleton, which was found in Lithuania, as well as the remains of a person who died in a healthcare facility and whose identity so far has not been established and objectively verified (Subsection 6.2). The term "an unidentified living person" refers to an adult patient or a child who due to his or her medical 
condition or age is not capable to provide identification information and whose identity so far has not been established and objectively verified (Subsection 6.3).

Under the Lithuanian Code of Criminal Procedure, an on-site examination of human remains in the case of suspicious death must be carried out by a forensic pathologist or other qualified medical professional (Article 206).

\section{STATE BODIES INVOLVED IN THE SEARCH FOR MISSING PERSONS}

In all four states, the police are the main governmental agency considering the search for missing persons and identification of unknown human remains. In some cases (for example, related to natural or technological disasters, forest fires or air accidents), national or regional emergency agencies would have priority in search and rescue operations. It is also common that there are no specialized unites with the police dedicated to the search for the missing (except Ukraine where the governmental commission has been established to coordinate the search for the missing people in the eastern part of the country).

\section{Russia}

In Russia, there is a system of governmental emergency services which includes fire brigades, airmobile rescue teams, mountain search units, as well as paramilitary rescue teams within the Russian Ministry of Emergency Situations. The Russian National Guard could participate in large-scale search and rescue operations. If the missing person fled from law enforcement or judicial authorities, the search would be conducted by the Russian Federal Penitentiary Service with the assistance of the local police and, if necessary, National Guard. The Russian Federal Security Service could participate in a search or search and rescue operation if the person who went missing is a foreign national.

In a case of criminal disappearance (the crimes described in Article $105 \mathrm{CC}$ - Homicide, 126 - Abduction or 127 - Illegal confinement), the search would be coordinated by the case investigator within the Russian Bureau of Investigations. The investigator closely cooperates with the police, in particular, its operative units. 


\section{Belarus}

The organizational structure concerning the search for the missing is similar to the one adopted by Russia. Besides the national police, there are national emergency services within the Belorussian Ministry of Emergency Situations. It is made up of firefighters, airmobile search and rescue units, and mountain rescue teams. All cases regarding criminal disappearances are handled by the criminal investigators within the Belarusian Bureau of Investigations, who receive assistance from local police.

\section{Ukraine}

Besides national police, there is the National Guard - a governmental agency conducting large-scale search and rescue operations. If necessary, the Ukrainian Security Service, Border Guard, and even the Army Forces could be engaged in a search for the missing. In 2016, the national Joint Center was created. It is a part of the Ukrainian National Security Service and employs specialists in the field of forensic human identification, crisis negotiations and experienced police operatives. It includes analytical, press and communication units and a call-centre. Its task is to coordinate search operations concerning the ones whose disappearance relate to the military conflict in eastern Ukraine. Thus, the Center functions only within the socalled Anti-Terrorist Operation Zone - the area which includes Doneck, Lugansk and nearby regions.

Another state-funded structure is the Ukrainian State Emergency Service, which task is to assist in search and rescue operations in an event of largescale natural or technological disasters.

\section{Lithuania}

The search for missing persons in Lithuania is being conducted by the national police in coordination with other emergency services including the country's Fire and Rescue Department, State Border Guard Service, Ministry of Transport and Communications, Ministry of Justice and the national Army Forces. Large-scale search and rescue operations could be coordinated by the Aeronautical Rescue Coordination Centre - a state-funded agency under the aegis of the Lithuanian Ministry of Transport and Communications. 


\section{THE IDENTIFICATION OF UNKNOWN HUMAN REMAINS}

Although the methods used in forensic human identification in all four countries are the same, there are some differences regarding prioritised methods and the identification procedure itself. In the Russain Federation, Belorus and Ukraine, it is not required to apply certain methods of identification in each case. The police operatives and criminal investigators are not obliged to conduct genetic identification every time they are dealing with unknown human remains. It is presumed that the correct identification could be provided by fingerprints, teeth and other anthropological features. In the cases, where the unidentified cadaver is in good condition, a visual identification with the help of missing person's relatives is allowed. It is also acceptable to identify an unknown cadaver through clothing and personal belongings, especially when there are photographs or video, on which the missing person is showed wearing those items. If necessary, the police operatives and criminal investigators can organize further examinations to verify prior results. Only in Lithuania, genetic identification is officially a prioritised method of identification. In all four, the on-site examination must be conducted in each case regarding unknown human remains to collect identification information. The case investigator is expected to describe in detail the deceased's gender, age, body constitution, skin, eye and hair colour, height, the shape and width of the person's head, document visible individual features such as scars, moles, warts, traces of conducted surgical operations, amputated limbs, injuries, any other physical defects, teeth, etc. The type, colour, origin, model, size and position of the clothes on the body, as well as any contaminations must be documented. The investigator should also describe personal items found near the body, such as keys, parking tickets, cigarette packs, food debris, tools, etc. In a case of advanced skeletonization, it is required to locate and recover the remains of clothing and footwear including fabric, buttons, buckles, belts, locks, to collect and examine personal belongings, such as rings, bracelets, earrings. In all four countries, photographing, fingerprinting and obtaining biological samples are considered obligatory.

In all four countries, a post-morten examination is an obligatory element in the cases regarding unidentified human bodies. It should be conducted 
by a forensic pathologist or exceptionally by qualified medical personal. The content of an autopsy report is usually regulated by the internal legal provisions. Standardized protocols are being used eliciting a detailed physical description of the person who's gone missing and circumstances surrounding his or her disappearance. They contain the outline of a human body to enhance recall and reporting of relevant information.

The methods used during the identification procedure are divided into three groups as follows.

1. Anatomical and morphological examination of the external characteristics of a body, such as gender, age, ethnicity, body type, height, dentition, fingerprints;

2. The examination of the internal characteristics relating to the basic structures of the human body including genetic, histological, serological and cytological studies;

3. Visual recognition of a body, clothing or other personal items by the missing person's relatives; this method of identification is used in the cases where the unknown body was not exposed to many destructive factors and, thus, is well-reserved.

In the Russian Federation, Belarus and Ukraine, the first two are considered more accurate and reliable. Other methods, such as visual identification, may still be used in some cases, but more often it is used for preliminary selection. It should be noted that the recommended procedure of visual identification is straightforward. Photographs of bodies are preferred to direct exposition. The identification should be done by the immediate next of kin, but, if possible, another person who knew should be asked to provide identification. The body must be prepared for visual recognition: damage should be covered, only the head and face should be exposed, the rest of the body should be covered. To provide additional evidence and also to reduce the witness's stress, the deceased's clothing and personal items should be identified separately from the body. The witnesses should be provided with professional psychological help. 


\section{Discussion}

In all four countries, the search for missing persons and unknown human remains identification are the tasks assigned to the national police forces. However, the lack of specialized units could be an issue. The search for the missing people should be given priority, especially in the cases concerning minors. Typically, this task is allocated to the police officers selected ad hoc, while they are not exempt from other non-related tasks. This goes hand in hand with a more selective approach, which in turn results in or contributes to a misleading appearance of intense activity. The search for the missing conducted only formally would be most probably less effective. Plus, the police officer should be adequately prepared for the task. Although the police are provided with the pertinent internal regulations and procedures, the level of details differs from state to state. For obvious reasons, it is impossible to cover all possible situations of human disappearances which limits the usefulness of existing regulations. Often, there is a lack of clear and precise recommendations adjusted to the typical situations of human disappearance. For example, there are no separate detailed procedures regarding minors, the elderly, the persons with mental health issues.

In today's world, it is essential to provide adequate media coverage using both traditional and online media. The abovementioned regulations omit this issue leaving the decision to be taken by the police officer who handles the case. The lack of pertinent detailed procedures and official recommendations might lead to some undesired results, for example, damaging information leakage or witness contamination. In our opinion, specialized search teams within the police should include internal press units. The interactions with the media must comply with well-known principles regarding the law enforcement's interactions with the media, such as the assessment of the possible results of information disclosure, continuity and the protection of the third parties' rights.

In all four abovementioned countries, among the national police, other state agencies could participate in the search and rescue operations. However, except for Lithuania and partly for Ukraine, no permanent bodies are coordinating large-scale searches. It can be an issue especially during the initial stage of the search when individual tasks should be allocated, taking into consideration 
each agencies' capabilities. We suggest organizing permanent state-funded coordination centres providing law enforcement with the ready-to-execute plans detailing each agency's tasks and areas of responsibility.

In the cases of criminal disappearances, appropriate proceedings should be instituted, and the search must be coordinated by the case investigator. National legal provisions require the presence of the qualified medical personal during on-site examinations, as well as obligatory post-morten examinations. There are also legal provisions concerning mandatory identification information collection and securement. Nonetheless, it appears that a catalogue containing typical circumstances indicating the criminal nature of disappearance should be provided by the law. On the one hand, it is for the police officer to decide whether there is the possibility of a crime being committed against the missing person. But the officer could be wrong with his or her initial diagnosis. In our opinion, the decision on the nature of a disappearance should be less discretional, the logic behind it should be more clear and controllable. The official and publicly available catalogue would protect the rights of the person who went missing and his or her relatives.

\section{Conclusions}

The search for missing persons and identification of unknown human remains should be the task assigned to specialized units with the police. Those units should include press services.

Often different state bodies are needed to participate in search and rescue operations. It is important to provide an adequate level of coordination, especially at the initial stages. Permanent coordination centres should be established along with the detailed coordination plans.

The circumstances indicating that the disappearance may be related to the crime should be defined by the law.

Identification information including photographs, fingerprints and biological samples must be collected and secured in each case regardless of its initial qualification. 


\section{References}

Ambroskin, V. (2018). The role of the National Police in maintaining legal order in the area of Special Operation of the United Forces. All-Ukrainian Scientific and Practical Seminar „Maintaining legal order in the area of Special Operation of the United Forces": Presentational thesis, Mariupol.

Code of Criminal Procedure of the Russian Federation of 18 December 2001. Available at: <https://www.consultant.ru/document/cons_doc_LAW_34481/ >. Access on: September 9, 2020.

Greene, K. S., Clarke, C. L. Pakes, F., Holmes, L. (2019). People with Dementia Who Go Missing: A Qualitative Study of Family Caregivers Decision to Report Incidents to the Police, Policing. A Journal of Policy and Practice, 13, 2, 241-253

How do they search for the missing people in Belarus. Available at: < https://www. mvd.gov.by/ru/news/>. Access on: September 9, 2020.

International treaty on the international search for missing persons with the Commonwealth of the Independent States of 10 December 2010. Available at: <http://fssprus.ru/2540100/ >. Access on: September 9, 2020.

Issue paper of the Council of Europe and the Commissioner for Human Rights on the missing persons and victims of enforced disappearances in Europe. Available at: < https://rm.coe.int/missing-persons-and-victims-of-enforced-disappearancein-europe-issue-/16806daalc >. Access on: September 9, 2020.

Joint decision of the Governments within the Commonwealth of Independent States on the international search for missing persons of 30 October 2015. Available at: < http://fssprus.ru/2540304/?print=1 >. Access on: September 9, 2020.

Joint regulations of the Belarusian Bureau of Investigations, Ministry of Internal Affairs and Ministry of Health of 25 September 2013 on the procedure for reviewing information about human deaths, on-scene inspections and the medical examinations of human remains. Available at: < http://www.pravo.by/document/?gu$\mathrm{id}=3961 \& \mathrm{p} 0=\mathrm{T} 21302659>$. Access on: September 9, 2020.

Joint regulations of the Ministry of Internal Affairs, Attorney General Office and the Bureau of Investigations of 16 January 2015 on the examination of the reports about human disappearances. Available at: < https://www.consultant.ru/document/ cons_doc_LAW_176970/>. Access on: September 9, 2020.

Karmanov, M. V., Smelov, P. A., Egorova E. A. (2015). The missing as a special aspect of ensuring the security of society demographic, Economics, statistics and informatics, 3, 187-190. ISSN 0322-788X.

Lubova, N. O., Filanina L. A. (2018). Searching for missing persons: legal and practical analysis, All-Ukrainian Scientific Conference's materials. Available 
at: < http://85.198.129.42/bitstream/123456789/3057/1/38.pdf >. Access on: September 9, 2020.

Mogavero, M.C. (2019). What Do Criminal Justice Students Know About Autism? An Exploratory Study Among Future Professionals. Journal of Police and Criminal Psychology, 34, 428-438. ISSN 0882-0783.

Morewitz S. J. (2016). Missing Persons: Forensic Sociology Factors [In:] S. J. Morewitz, C. S. Coll (Ed(s).), Handbook of Missing Persons, Springer, Switzerland, 95, 93-103. ISBN 9783319401973.

Nikitin, I. L., Dytchenko G. V. (2013). The procurator's control over the legality of covered police operations and its documentation, Saint-Petersburg Law Institution (branch) of the Academy of the Prosecutor General's Office of the Russian Federation, Sankt-Petersburg.

Official statistical data on missing persons in the Republic of Belarus. Available at:<http://elib.amia.by/bitstream/docs/2696/1/problemi_borbi2019_115.pdf >. Access on: September 9, 2020.

Official statistical data on missing persons in the Republic of Lithuania. Available at: $<$ https://osp.stat.gov.lt/statistiniu-rodikliu-analize?indicator=S3R0047>. Access on: September 9, 2020.

Official statistical data on the missing persons in the Russian Federation. Available at: <https://мвд.pф/opendata/7727739372-MVDGIAC311>. Access on: September 9, 2020.

Regulations of the Ministry of Internal Affairs of the Republic of Lithuania of 3 March 2017 on the organization of the register of missing persons, unidentified human remains and unidentified living persons. Available at: <https://www.e-tar.lt/portal/ lt/legalAct/ce77c810001111e78034be159a964f47>. Access on: September 9, 2020.

There are more chances to survive if the information about the disappearance received timely. Available at: <https://68.мвд.pф/Prjamaja_rech/item/16395536/>. Access on: September 9, 2020.

Issue paper of the Council of Europe and the Commissioner for Human Rights, 2016. Available at: <https://rm.coe.int/missing-persons-and-victims-of-enforceddisappearance-in-europe-issue-/16806daalc )> . Access on: September 9, 2020.

Law of Ukraine of 18 February 1992 on covert operations. Available at: <https://zakon.rada.gov.ua/laws/show/2135-12 >. Access on: September 9, 2020.

Federal law of 8 August 1995 No. 144-FZ on covert operations. Available at: <https:// www.consultant.ru/document/cons_doc_LAW_7519/>. Access on: September 9, 2020. 
Penal Code of the Russian Federation of 13 June 1996. Available at: <http://www.consultant.ru/document/cons_doc_LAW_10699/>. Access on: September 9, 2020.

Federal law of 25 July 1998 No. 128-FZ on the state-provided fingerprint registration in the Russian Federation. Available at: <https://www.consultant.ru/document/ cons_doc_LAW_19562/>. Access on: September 9, 2020.

European Court of Human Rights. Judgement of 8 July 1999 in the case of Çakıcı v. Turkey. Available at: <https://hudoc.echr.coe.int/eng\#\{\%22itemid\%22:[\%22001-58282\%22]\} >. Access on: September 9, 2020.

Penal Code of Ukraine of 15 April 2001. Available at: <https://zakon.rada.gov.ua/ laws/main/2341-14 >. Access on: September 9, 2020.

Law of the Republic of Belarus of 17 July 2007 on the agencies of internal affairs. Available at: <https://kodeksy-by.com/zakon_rb_ob_organah_vnutrennih_del.htm>. Access on: September 9, 2020.

Federal law of 3 December 2008 No. 242-FZ on the state-provided genetic registration in the Russian Federation. Available at: <https://www.consultant.ru/document/ cons_doc_LAW_82263/>. Access on: September 9, 2020.

European Court of Human Rights. Judgement of 18 September 2009 in the case of Varnava and Others v. Turkey. Available at: <https://hudoc.echr.coe.int/eng\#\{\%22itemid\%22:[\%22001-94162\%22]\}>. Access on: September 9, 2020.

Code of Criminal Procedure of Ukraine of 13 April 2012. Available at: $<$ https://zakon. rada.gov.ua/laws/card/4651-17>. Access on: September 9, 2020.

Law of the Republic of Lithuania of 25 June 2015 on the police, Available at: $<$ https://e-seimas.lrs.lt/portal/legalAct/lt/TAD/605bccb020b011e58a4198cd62929b7a >. Access on: September 9, 2020.

Law of the Republic of Belarus of 15 July 2015 on covert operations. Available at: $<$ https://kodeksy-by.com/zakon_rb_ob_operativno-rozysknoj_deyatel_nosti. htm>. Access on: September 9, 2020.

Law of Ukraine of 12 July 2018 on the legal status of the missing persons. Available at: <https://zakon.rada.gov.ua/laws/show/2505-19>. Access on: September 9, 2020.

Code of Criminal Procedure of the Republic of Lithuania of 14 March 2002. Available at: <https://www.e-tar.lt/portal/lt/legalAct/TAR.EC588C321777>. Access on: September 9, 2020.

Code of Criminal Procedure of the Republic of Belarus of 16 July 1999. Available at: <https://etalonline.by/document/?regnum=HK9900295>. Access on: September $9,2020$. 